ARTICLE

https://doi.org/10.1038/s41467-019-11987-z

\title{
Tropane alkaloids biosynthesis involves an unusual type III polyketide synthase and non-enzymatic condensation
}

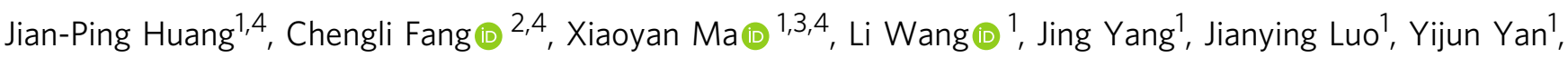
Yu Zhang (i) ${ }^{2} \&$ Sheng-Xiong Huang (1) ${ }^{1}$

The skeleton of tropane alkaloids is derived from ornithine-derived $\mathrm{N}$-methylpyrrolinium and two malonyl-CoA units. The enzymatic mechanism that connects $\mathrm{N}$-methylpyrrolinium and malonyl-CoA units remains unknown. Here, we report the characterization of three pyrrolidine ketide synthases (PYKS), AaPYKS, DsPYKS, and AbPYKS, from three different hyoscyamine- and scopolamine-producing plants. By examining the crystal structure and biochemical activity of AaPYKS, we show that the reaction mechanism involves PYKSmediated malonyl-CoA condensation to generate a 3-oxo-glutaric acid intermediate that can undergo non-enzymatic Mannich-like condensation with $\mathrm{N}$-methylpyrrolinium to yield the racemic 4-(1-methyl-2-pyrrolidinyl)-3-oxobutanoic acid. This study therefore provides a long sought-after biosynthetic mechanism to explain condensation between $\mathrm{N}$-methylpyrrolinium and acetate units and, more importantly, identifies an unusual plant type III polyketide synthase that can only catalyze one round of malonyl-CoA condensation.

\footnotetext{
${ }^{1}$ State Key Laboratory of Phytochemistry and Plant Resources in West China, and CAS Center for Excellence in Molecular Plant Sciences, Kunming Institute of Botany, Chinese Academy of Sciences, Kunming 650201, China. ${ }^{2}$ The Key Laboratory of Synthetic Biology, and CAS Center for Excellence in Molecular Plant Sciences, Institute of Plant Physiology and Ecology, Chinese Academy of Sciences, Shanghai 200032, China. ${ }^{3}$ School of Chemistry and Chemical Engineering, Sichuan University of Science \& Engineering, Zigong 643000, China. ${ }^{4}$ These authors contributed equally: Jian-Ping Huang, Chengli Fang, Xiaoyan Ma. Correspondence and requests for materials should be addressed to Y.Z. (email: yzhang@sippe.ac.cn) or to S.-X.H. (email: sxhuang@mail.kib.ac.cn)
} 
$\mathrm{T}$ ropane alkaloids (TA) are an important class of secondary metabolites with a characteristic 8-azabicyclo[3.2.1]octane ring in their chemical structures, and occur mainly in many members of the plant families Erythroxylaceae and Solanaceae ${ }^{1,2}$. Among the $>200$ known TA, the anticholinergic drugs atropine (the racemic hyoscyamine), and scopolamine as well as the stimulant cocaine (Fig. 1a) are most prominent and have been used for a long time as medicinals worldwide ${ }^{2,3}$.

The carbon atom source of TA is known from the amino acid ornithine $^{4-7}$ and acetate units ${ }^{8-10}$ for a long time by elaborate isotope-labeling experiments. In recent 20 years, biochemical studies have demonstrated that the intermediate $\mathrm{N}$-methylpyrrolinium cation (1) was biosynthesized from amino acid ornithine by three enzymes, the ornithine decarboxylase (ODC) ${ }^{11}$, putrescine $N$-methyltransferase ${ }^{12,13}$, and $N$-methylputrescine oxidase (MPO) $)^{14-16}$ (Fig. 1b). Very recently, tropinone biosynthesis has been investigated ${ }^{17}$, and it has been shown that the key intermediate 4-(1-methyl-2-pyrrolidinyl)-3-oxobutanoic acid (2) ${ }^{18}$ results from an atypical type III polyketide synthase (PKS) AbPYKS catalyzed condensation between $\mathbf{1}$ and malonyl-CoA, whereas tropinone is formed by a P450 enzyme AbCYP82M3mediated oxidation and cyclization of racemic 2 . However, this very unusual PYKS-mediated condensation mechanism between 1 and acetate units still remains unknown. Herein, we report the characterization of three PYKSs, AaPYKS, DsPYKS, and AbPYKS, from three respective plants, Anisodus acutangulus, Datura stramonium, and Atropa belladonna as well as the condensation mechanism based on the crystal structures of AaPYKS.

\section{Results}

Identification of type III PKS genes from three solanaceous plants. The hyoscyamine and scopolamine are found in a variety of solanaceous plants including A. acutangulus, A. belladonna, and $D$. stramonium ${ }^{1,2,19}$. Their biosynthesis occurs in the plant roots $^{20,21}$, which provides the advantage to study the biosynthesis using the plant hairy roots culture ${ }^{22}$. To facilitate gene discovery efforts, we constructed the hairy roots of A. acutangulus, A. belladonna, and D. stramonium, and confirmed the production of hyoscyamine and scopolamine by HPLC analysis (Supplementary Fig. 1). Previous labeling studies ${ }^{4-10,23-25}$ demonstrated that the second ring of TA originates from two acetate units indicating the involvement of PKS. De novo transcriptome assembly of three

a
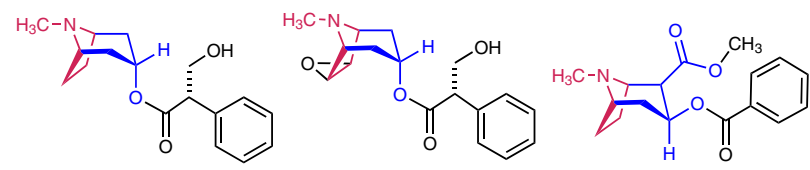

Hyoscyamine

Scopolamine

Cocaine

b
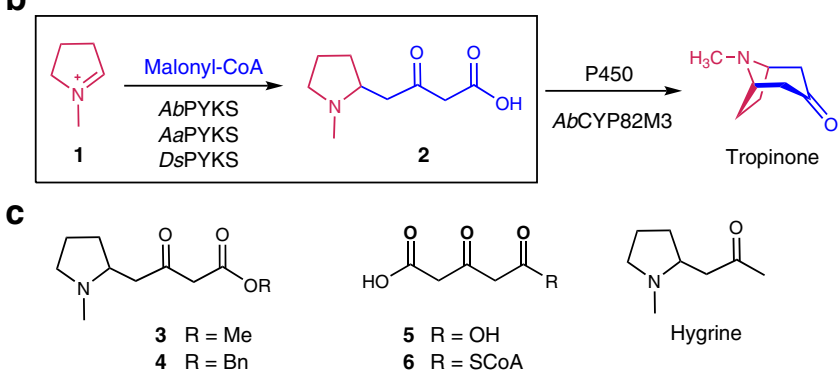

Fig. 1 The chemical structures mentioned in this study and the biosynthetic pathway of tropinone. a The tropane alkaloids. $\mathbf{b}$ The tropinone biosynthesis pathway with the current study highlighted in the box. c The chemical structures of other compounds established hairy roots was generated using the Hiseq platform. By a combination of direct screening of the transcriptome assembly annotations, BLAST searches and rapid amplification of cDNA ends, full-length transcripts of four, five, and two putative type III PKS unigenes were obtained from three hairy roots, respectively (Supplementary Table 1). Subsequent phylogenetic tree (Supplementary Fig. 2) and amino-acid sequence alignment (Supplementary Fig. 3) indicated that $A b \mathrm{PKS} 2, A a \mathrm{PKS} 4, A a \mathrm{PKS} 2$, $A b \mathrm{PKS} 3$, and $D s \mathrm{PKS} 1$ from three different plants, were in a clade more divergent with others and the amino-acid sequence of $A b \mathrm{PKS} 3$ is identical with the reported $A b \mathrm{PYKS}^{17}$. This information suggests that the five PKSs are presumably involved in TA biosynthesis.

Determining the enzyme activity of putative PYKS. In order to functionally assign these putative type III PKSs, the five proteins were heterologously expressed in Escherichia coli (E. coli) (Supplementary Fig. 4) and analyzed in vitro for their activity toward putative substrates, chemically synthesized 1 (Supplementary Fig. 5) and malonyl-CoA. Interestingly, liquid chromatographymass spectrometry (LC-MS) analysis showed the appearance of a new peak at $m / z 186$ in the AaPKS2, AbPYKS, and DsPKS1 catalyzed reactions that was not present in AbPKS2 (Fig. 2 and Supplementary Fig. 6a) (AaPKS4 forms inclusion bodies and was thus not characterized further). This new peak has the same MS and retention time as that of chemically synthesized 2 (Fig. 2 and Supplementary Fig. 7). Therefore, we established that AaPKS2 and DsPKS1 are involved in TA biosynthesis and named them as $A a$ PYKS and DsPYKS, respectively ${ }^{17}$. However, the recent Barry and co-workers' work did not determine the absolute configuration of the enzymatic product 2 owing to its inherent instability 17,18 . To solve this problem, we scaled up the enzymatic reactions and treated the product 2 with $\mathrm{SOCl}_{2}$ either in methanol or benzyl alcohol to afford the expected esters (3 and 4) (Fig. 1c and Supplementary Fig. 8). Then, the chiral and racemic $\mathbf{3}$ and $\mathbf{4}$ were chemically synthesized as standards for comparisons (Supplementary Fig. 8). LC-MS analysis revealed both the methyl and the benzyl product of $\mathbf{2}$ matched the standards $\mathbf{3}$ and $\mathbf{4}$ (Supplementary Fig. 9). Whereas, the optical rotation data of enzymatic product 4 is around -4.5 comparing to the value of -31.2 for synthesized $S$-configuration 4 (Supplementary Fig. $7 \mathrm{~b}$ ), suggesting that the enzymatic product 2 is a racemate.

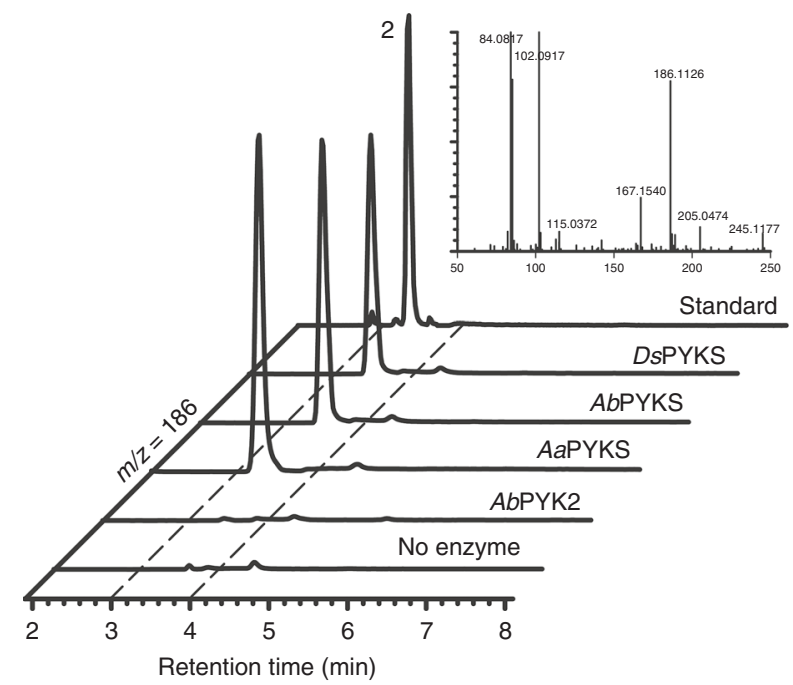

Fig. 2 LC-MS chromatograms at $[\mathrm{M}+\mathrm{H}]^{+}=186$ of product $\mathbf{2}$ in enzymatic reactions for DsPYKS, AbPYKS, AaPYKS or AbPKS2 using 1 and malonylCoA as substrates 
Table 1 Data collection and refinement statistics

\begin{tabular}{|c|c|c|}
\hline & AaPYKS-COB & AaPYKS-6 \\
\hline \multicolumn{3}{|l|}{ Data collection } \\
\hline Space group & $P 3_{2} 21$ & $P 3_{2} 21$ \\
\hline \multicolumn{2}{|l|}{ Cell dimensions } & $108.4,108.4,191.5$ \\
\hline$\alpha \beta \gamma\left({ }^{\circ}\right)$ & $90,90,120$ & $90,90,120$ \\
\hline Resolution $(\AA)$ & $\begin{array}{l}50.00-2.00 \\
(2.03-2.00)\end{array}$ & $\begin{array}{l}50.00-2.53 \\
(2.57-2.53)\end{array}$ \\
\hline$R_{\text {sym }}$ or $R_{\text {merge }}$ & $0.104(0.926)$ & $0.092(0.472)$ \\
\hline$|/ \sigma|$ & $24.9(2.7)$ & $34.1(8.0)$ \\
\hline Completeness (\%) & $100(100)$ & $100(100)$ \\
\hline Redundancy & $11.0(10.1)$ & $16.4(16.4)$ \\
\hline \multicolumn{3}{|l|}{ Refinement } \\
\hline Resolution $(\AA)$ & $47.06-2.00$ & $47.15-2.53$ \\
\hline No. reflections & 85,063 & 43,997 \\
\hline$R_{\text {work }} / R_{\text {free }}$ & $0.175 / 0.194$ & $0.164 / 0.191$ \\
\hline No. atoms & 6466 & 6296 \\
\hline Protein & 5805 & 5778 \\
\hline Ligand/ion & 34 & 114 \\
\hline Water & 627 & 404 \\
\hline \multicolumn{3}{|l|}{$B$-factors } \\
\hline Protein & 27.3 & 32.9 \\
\hline Ligand/ion & 39.8 & 63.9 \\
\hline Water & 37.2 & 38.6 \\
\hline \multicolumn{3}{|l|}{ R.m.s. deviations } \\
\hline Bond lengths $(\AA)$ & 0.01 & 0.01 \\
\hline Bond angles $\left({ }^{\circ}\right)$ & 1.14 & 1.45 \\
\hline
\end{tabular}

Structural basis for the PYKS catalytic mechanism. Plant type III PKSs are a family of enzymes known to catalyze the iterative decarboxylative condensation of malonyl-CoA upon CoAtethered substrates and could generate a variety of natural products with aromatic ring ${ }^{26,27}$. In this study, the type III PKSs were characterized to react onto the non-CoA-tethered substrate 1 to give a non-aromatic product, indicating a potential new family of type III PKS. To understand the structural basis for the catalytic mechanism, we determined a crystal structure of $A a \mathrm{PYKS}$ at 2.0 $\AA$ (AaPYKS-COB, Table 1; PDB ID: 6J1M). The overall structure of the dimeric AaPYKS-COB is highly homologous to those of previously reported type III PKSs (Fig. 3a and Supplementary Fig. 10 $)^{26,27}$. The surface exposed characteristic CoA-binding tunnel reaches into the inner active center, where the conserved catalytic triad C166-H305-N338 resides as those in other type III PKSs. Surprisingly, we observed a large electron density extending from the thiol moiety of C166 (Fig. 3b). Inspired by previous structure of pentaketide chromone synthase (PCS) showing a copurified $\mathrm{CoASH}$ in the active center ${ }^{28}$, we suspect that the $A a$ PYKS-COB prepared from E. coli cells probably utilized the endogenous malonyl-CoA to yield a reaction intermediate covalently bound to the thiol group. To confirm our hypothesis, we explored the possible covalent modification on $\mathrm{C} 166$ of purified AaPYKS-COB through mass spectrometry. The results in Supplementary Fig. 11 clearly show the presence of a C166containing peptide with an additional mass of $128 \mathrm{Da}$, corresponding to exact mass of a 4-carboxy-3-oxobutanoyl (COB) moiety (Fig. 3c). The 4-carboxy-3-oxobutanoyl thioester could be readily fit into the electron density (Fig. 3b).

The crystal structure of $A a \mathrm{PYKS}-\mathrm{COB}$ also graphically explains the limited round of elongation AaPYKS could catalyze. In the structure, the 4-carboxy-3-oxobutanoyl moiety is stabilized by multiple polar interactions with R134, H305, N338, and S340 and hydrophobic interactions with M139, F217, L256, and L258 (Fig. 3c). Notably, R134 and S340 make a salt-bridge and hydrogen bond interactions with the carboxy group of the thioester, respectively, which serves as a gate to prevent entry to the buried pocket near the active center, and consequently inhibits further chain elongation (Fig. 3d). Alanine, threonine, or serine substitution of R134 resulted in significant decrease of activity, highlighting the key role of R134 for AaPYKS-catalyzed one-round malonyl-CoA condensation (Supplementary Fig. 6b). To explore the necessity of hydrogen bonding between S340 and the carboxy group of the thioester, amino acids without hydroxyl group (leucine, glycine, and valine) or having more steric hindrance (leucine and valine) were selected for site mutation of S340. All the three mutations showed much decreased activity (Supplementary Fig. 6c), showing the importance of hydrogen bonding to the enzymatic activity. In addition, the presence of a leucine residue in the non-functional $A b \mathrm{PKS} 2$ at the corresponding S340 position of $A a$ PYKS also supports the key role for S340.

Our in vitro enzymatic experiment detects rapid conversion of malonyl-CoA to 3-oxo-glutaric acid (5) by $A a \mathrm{PYKS}$ in the absence of 1 (Supplementary Fig. 12), implicating that malonylCoA could help release the covalently bound intermediate and reactivates the enzyme. We therefore soaked the crystal of $A a \mathrm{PYKS}-\mathrm{COB}$ with high concentration of malonyl-CoA and determined another structure at $2.5 \AA$ (AaPYKS-6; PDB ID: $6 \mathrm{~J} 1 \mathrm{~N}$; Table 1 and Supplementary Fig. 10b). Unexpectedly, we observed an even larger electron density than that in AaPYKS$\mathrm{COB}$ in the tunnel, the upper part of which is identical to that of COB moiety in the AaPYKS-COB structure and the lower part of which fills up the CoA tunnel (Fig. 3e, f). The expected intermediate 4-carboxy-3-oxobutanoyl-CoA (6) could be readily fitted into the density. In the structure of AaPYKS-6, the carboxyl moiety makes the same interactions as in structure of $A a \mathrm{PYKS}$ $\mathrm{COB}$, and the sulfur of $\mathrm{C} 166$ is close to the $\mathrm{C} 1$ and $\mathrm{C} 3$ atoms of 6 (Fig. 3e, f). The structure suggests we trapped another intermediate 6 and the $\mathrm{C} 166$ is ready to attack the thiol ester carbonyl to recapture the COB moiety. To our knowledge, this is the first type III PKS structure trapped with elongated and CoAtethered $\beta$-keto intermediate ${ }^{29}$.

The crystal structures clearly suggest that the PYKSs take the solo malonyl-CoA as both starter and extender unit. This feature is similar to that of the PCS and octaketide synthase (OKS) from Aloe arborescens ${ }^{28,30,31}$, which have been established as a novel class of plant type III PKSs because both enzymes accept the sole malonyl-CoA as both starter and extender unit to catalyze five- or eight-round malonyl-CoA condensations. Consistently, AaPYKS, $A b P Y K S$, and DsPYKS all have the characteristic leucine residue at 258,259, and 259, respectively, corresponding to Leu266 in both PCS and OKS (Supplementary Fig. 3), which was proposed to determine the selectivity of the starter molecule from traditional $p$-coumaroyl-CoA to the sole malonyl-CoA unit ${ }^{28,32}$. Alanine substitution of AaPYKS L258 led to remarkable enzymatic activity reduction (Supplementary Fig. 6). This information also suggests that all the three PKSs catalyze the sole malonyl-CoA condensation to generate $\mathbf{5}$, then condense with 1 to yield 2 rather than 1 reacts with malonyl-CoA first (Supplementary Fig. 13). This unique order of condensations is also preferred by the feeding experiments-based TA biosynthesis by Robins et al. ${ }^{23}$.

Non-enzymatic condensation 1 with 5 . To determine how the non-CoA-tethered substrate $\mathbf{1}$ interacts with the enzyme, high concentration of $\mathbf{1}$ was soaked into the crystal of $A a$ PYKS-COB. However, the active center of the resulting crystal structure was highly similar to that of the structure AaPYKS-COB; and the C166 is still covalently bound with the COB moiety (Supplementary Fig. 14a). This result suggests that 1 may not be capable 
a

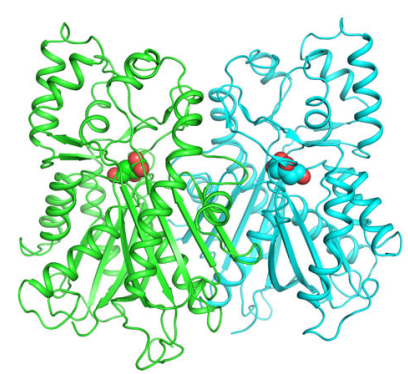

d

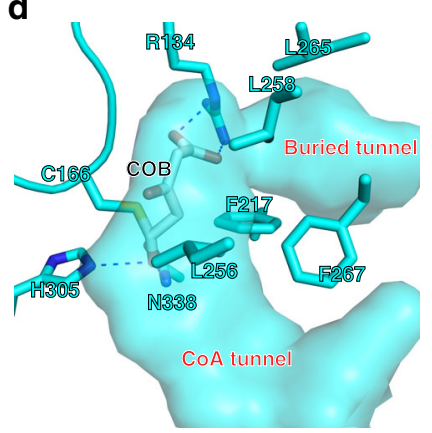

b

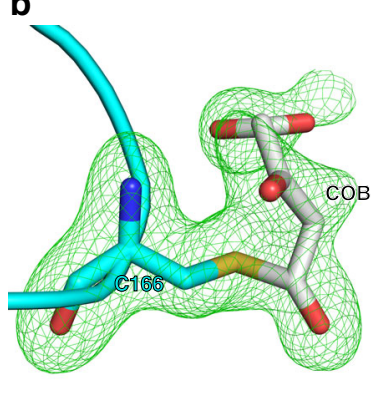

e

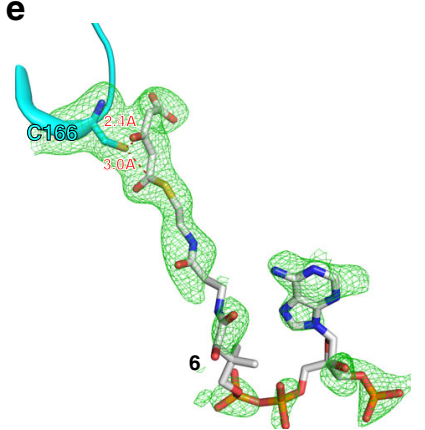

C

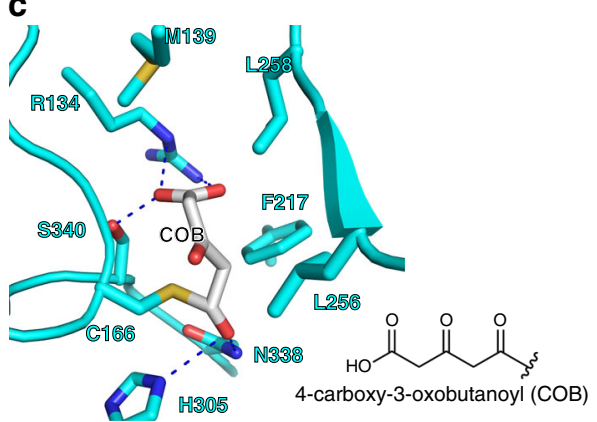

f

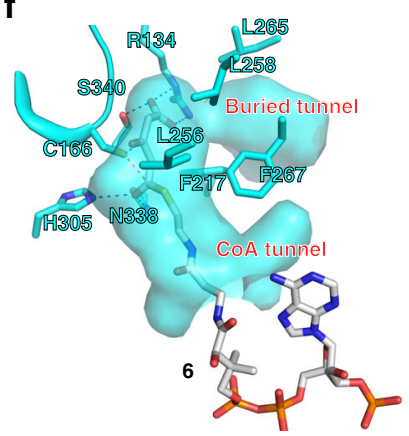

Fig. 3 Crystal structures of AaPYKS-COB (PDB ID: 6J1M) and AaPYKS-6 (PDB ID: 6J1N). a AaPYKS-COB is a dimer (cyan and green ribbon). The 4carboxy-3-oxobutanoyl (COB) thioester is shown as spheres. $\mathbf{b}$ The $\mathrm{F}_{\mathrm{O}}-\mathrm{F}_{\mathrm{C}}$ electron density polder map contoured at $5 \sigma$ of the catalytic residue $\mathrm{C} 166$ and the covalently bound COB. $\mathbf{c}$ The detailed interactions of COB with AaPYKS residues. $\mathbf{d}$ The surface presentation of AaPYKS shows the inner tunnels. e The $\mathrm{F}_{\mathrm{O}}-\mathrm{F}_{\mathrm{C}}$ electron density polder map contoured at $3 \sigma$ of the catalytic residue $\mathrm{C} 166$ and $\mathbf{6}$. $\mathbf{f}$ The surface presentation of AaPYKS-6 shows the inner tunnels. $\mathrm{N}$, $\mathrm{O}, \mathrm{S}$, and $\mathrm{P}$ atoms are colored as blue, red, yellow, and orange, respectively. $\mathrm{C}$ atoms of protein residues and small molecules are colored as cyan and white, respectively

of releasing the $\mathrm{COB}$ moiety from $\mathrm{C} 166$ in the active center. Above information in conjunction with the production of racemic $\mathbf{2}$ prompts us to propose that the condensation $\mathbf{1}$ with $\mathbf{5}$ is nonenzymatic. We next sought to obtain evidence for the nonenzymatic reactions by performing in vitro reactions between the intermediate $\mathbf{5}$ and $\mathbf{1}$ in the conditions of with and without enzyme AaPYKS, respectively. As expected, both conditions did yield the same product 2 , and the kinetic analysis showed that there is no reaction velocity difference for the conditions of with or without enzyme (Supplementary Fig. 14b). These results clearly demonstrate that the racemic $\mathbf{2}$ is afforded in a nonenzymatic Mannich-like condensation. Hygrine (Fig. 1c) is a decarboxylative product of 2 biosynthetically 17,18 . Coincidentally, all the isolated hygrine from different plants is racemic ${ }^{33}$, corroborating the racemic feature of $\mathbf{2}$ from spontaneous condensation in TA biosynthesis.

\section{Discussion}

Based on the three structures and the in vitro reactions, we proposed a detailed mechanism for the identified PYKSs (Fig. 4). First, the $A a \mathrm{PYKS}$ runs one-round malonyl-CoA condensation using conserved $\mathrm{Cys}_{166}-\mathrm{His}_{305}-\mathrm{Asn}_{338}$ catalytic triad to afford 6 in the active site (Fig. 3f), then the thiol group of Cys ${ }_{166}$ attacks the thiol ester carbonyl of 6 (Fig. 3c) to recapture the COB moiety. Subsequently one molecule of water could come into the active site to form the hydrogen bonds with $\mathrm{His}_{305}$ and the carbonyl as the case of the plant PKS BAS-mediated reaction ${ }^{34}$. The nucleophilic attack to thiol ester by this water would yield $\mathbf{5}$. Additional malonyl-CoA will come into the active site to push 5 out of the pocket to undergo the spontaneous condensation with $\mathbf{1}$ to yield $\mathbf{2}$.

The mechanism of Mannich-like condensation between $\mathbf{1}$ and acetate units has intrigued chemists for two decades ${ }^{23-25}$. Robert
Robinson finished the chemical synthesis of tropinone in one pot by the addition of succinaldehyde, methylamine, and salt of 3 oxo-glutaric acid (5) at physiological pH condition with the $42 \%$ yield in 1917 (Supplementary Fig. 15) ${ }^{35}$, which has been widely applauded and has become the first synthesis classic. This classic synthesis route stimulated a proposal by Robinson, suggesting the biosynthesis of tropinone might occur via an analogous route involving the pyrrolidine ring moiety and $\mathbf{5}$ to furnish the tropane ring $^{18}$. In this study, we clearly demonstrated that AaPYKS only takes one-round of malonyl-CoA condensation to form free acid 5, and then undergo the non-enzymatic Mannich-like condensation with the substrate $N$-methylpyrrolinium (1) to afford 2 (Fig. 4). This biosynthetic route is analogous to the Robinson's proposal and suggests that the classic synthetic route reported $>$ 100 years ago is biomimetic. Overall, our experiments have solved the longstanding question for reaction mechanism between $\mathbf{1}$ and acetate units in TA biosynthesis.

There is no reported type III PKS that takes one round of sole malonyl-CoA condensation in natural product biosynthesis, thereby, PYKS may represent an emerging class of plant type III PKSs. In addition, the key step of granatane alkaloids (GA) ${ }^{36}$ and lycopodium alkaloids ${ }^{37,38}$ biosynthesis was proposed to be similar with that of $\mathrm{TA}^{17}$. Our findings suggest a unifying biosynthetic mechanism for a wide range of plant alkaloids including granatane and lycopodium families (Supplementary Fig. 16). Therefore, the mechanism depiction could provide a molecular blueprint for generating structure diversified TA, GA, and lycopodium alkaloids.

\section{Methods}

General experimental procedures. All moisture or oxygen-sensitive reactions were carried out under an argon or nitrogen atmosphere in oven or heat-dried flasks. The solvents used were purified by distillation over the drying agents 


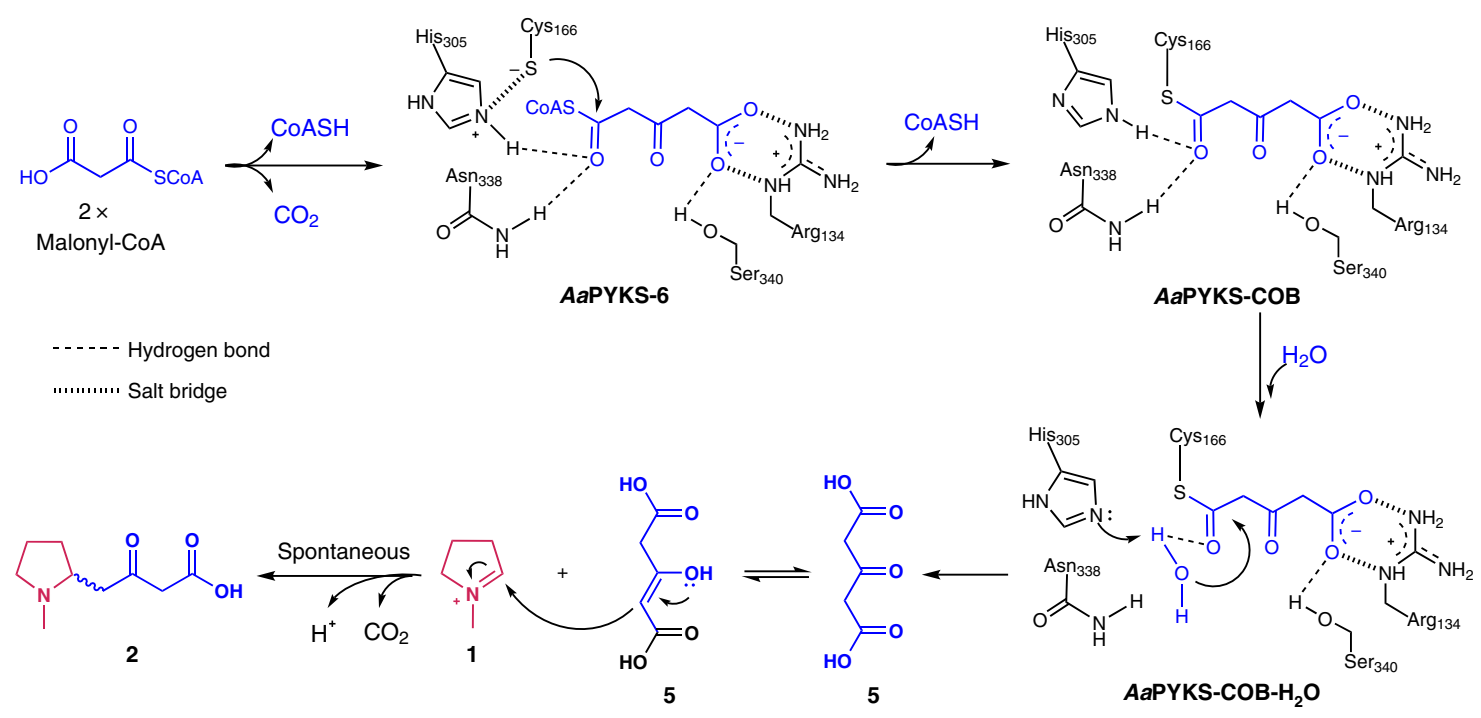

Fig. 4 Proposed mechanism for AaPYKS-catalyzed reactions

indicated and were transferred under argon: THF $(\mathrm{Na}), \mathrm{CH}_{2} \mathrm{Cl}_{2}\left(\mathrm{CaH}_{2}\right), \mathrm{MeOH}$ $(\mathrm{Mg}), \mathrm{NEt}_{3}\left(\mathrm{CaH}_{2}\right)$. All reactions were monitored by thin-layer chromatography on silica gel F254 plates using UV light as visualizing agent (if applicable), and a solution of phosphomolybdic acid $\left(50 \mathrm{~g} \mathrm{~L}^{-1}\right)$ in EtOH followed by heating as developing agents. The products were purified by flash column chromatography on silica gel (200 -300 meshes from the Anhui Liangchen Silicon Material Company in China). ${ }^{1} \mathrm{H}$ NMR and ${ }^{13} \mathrm{C}$ NMR spectra were recorded in $\mathrm{D}_{2} \mathrm{O}, \mathrm{CDCl}_{3}$ or acetone- $d_{6}$ solution on a Bruker AM $400 \mathrm{MHz}$ instrument. Chemical shifts were denoted in ppm $(\delta)$, and calibrated by using residual undeuterated solvent $\mathrm{D}_{2} \mathrm{O}(4.79 \mathrm{ppm}), \mathrm{CDCl}_{3}(7.27 \mathrm{ppm})$, acetone- $d_{6}(2.05 \mathrm{ppm})$ or tetramethylsilane $(0.00 \mathrm{ppm})$ as internal reference for ${ }^{1} \mathrm{H}$ $\mathrm{NMR}$ and the deuterated solvent $\mathrm{CDCl}_{3}(77.00 \mathrm{ppm})$, acetone- $d_{6}(29.8 \mathrm{ppm})$ or tetramethylsilane $(0.00 \mathrm{ppm})$ as internal standard for ${ }^{13} \mathrm{C}$ NMR. The following abbreviations were used to explain the multiplicities: $s=$ singlet, $d=$ doublet, $t=$ triplet, $\mathrm{q}=$ quartet, $\mathrm{br}=$ broad, $\mathrm{brs}=$ broad singlet, $\mathrm{m}=$ multiplet. Optical rotation data was measured on a Rudolph Autopol VI Automatic Polarimeter. The highresolution mass spectral analysis (HRESIMS) data were measured on Agilent G6230 Q-TOF mass instrument (Agilent Corp., USA) by means of the ESI technique. LC-MS analysis was conducted on AGILENT 1290/6530 system. HPLC analysis was conducted on a HITACHI Chromaster system equipped with a DAD detector, a YMCTriart $\mathrm{C}_{18}$ column $(250 \mathrm{~mm} \times 4.6 \mathrm{~mm}$ i.d., $5 \mu \mathrm{m})$, and a flow rate of $1.0 \mathrm{~mL} \mathrm{~min}^{-1}$ at a column temperature of $25^{\circ} \mathrm{C}$.

Plant materials. The seeds of A. acutangulus, A. belladonna, and D. stramonium were collected from Yunnan province, Hunan province, and Heilongjiang province of China, respectively. The hairy root induction was performed using young plant tissues $^{39}$. In brief, leaf disks and stem segments prepared from 2-6-week-old sterilized plant seedlings were inoculated with Agrobacterium tumefaciens strain $\mathrm{C} 58 \mathrm{Cl}$ (pRiA4) suspended in liquid Murashige and Skoog (MS) medium containing $30 \mathrm{~g} \mathrm{~L}^{-1}$ sucrose and $100 \mu \mathrm{m}$ acetosyringone, incubated in darkness on cocultivation solid $1 / 2$ MS medium containing $30 \mathrm{~g} \mathrm{~L}^{-1}$ sucrose and $100 \mu \mathrm{m}$ acetosyringone, disinfected on solid $1 / 2$ MS medium containing $30 \mathrm{~g} \mathrm{~L}^{-1}$ sucrose and $0.5 \mathrm{~g} \mathrm{~L}^{-1}$ cefotaxime, and sub-cultured in solid or liquid $\frac{1}{2} \mathrm{MS}$ medium with $30 \mathrm{~g} \mathrm{~L}^{-1}$ sucrose.

Scopolamine and hyoscyamine analysis. Scopolamine and hyoscyamine were extracted from $40^{\circ} \mathrm{C}$ dried hairy roots ${ }^{40}$. An extraction solvent of chloroform: methanol: $25 \%$ ammonia $\left(15: 5: 1, \mathrm{v} / \mathrm{v} / \mathrm{v} ; 100 \mathrm{~mL} \mathrm{~g}^{-1}\right.$ sample) was added to the weighed sample $(200 \mathrm{mg})$, vortexed, and sonicated for $30 \mathrm{~min}$, and then centrifuged for $30 \mathrm{~min}$ at room temperature (rt). The supernatant was evaporated to dryness at $40^{\circ} \mathrm{C}$, and the resulting sample was dissolved in $5 \mathrm{~mL}$ of $0.5 \mathrm{M}$ sulfuric acid and $15 \mathrm{~mL}$ chloroform. The sulfuric acid phase was collected and adjusted to $\mathrm{pH} \sim 10$ with ice-bathed $25 \%$ ammonia, and then alkaloids were extracted from the sulfuric acid phase with $5 \mathrm{~mL}$ of chloroform thrice. The combined chloroform phase was evaporated to dryness at $40^{\circ} \mathrm{C}$, and the resulting sample was dissolved in $1 \mathrm{~mL}$ methanol for HPLC analysis. The mobile phase was made up from $57 \%$ or $59 \%$ HPLC gradient methanol and $43 \%$ or $41 \%$ HPLC gradient water (containing $50 \mathrm{~mm}$ ammonium acetate and adjust $\mathrm{pH}$ to 4.6 by acetic acid). The chromatogram was monitored by detecting the absorbance at $215 \mathrm{~nm}$. Standards for hyoscyamine and scopolamine (Yuanye, Shanghai, China) were prepared in methanol at a final concentration of $1 \mathrm{mg} \mathrm{mL}^{-1}$. Hyoscyamine and scopolamine peak in samples were identified by comparing their retention time and UV spectra with those of standards and confirmed by MS spectra. Quantitative analysis was performed using standard curves of hyoscyamine and scopolamine based on the peak area.
Time-course culture of hairy roots and de novo transcriptome sequencing. Fresh hairy roots $(0.2 \mathrm{~g})$ were transferred to $100 \mathrm{~mL}$ liquid $1 / 2$ MS medium with $30 \mathrm{~g} \mathrm{~L}^{-1}$ sucrose and maintained in darkness at $25^{\circ} \mathrm{C}$ on a rotary shaker (110 rpm.). Samples of cultured hairy roots were collected every 5 days, and the fresh weights, dry weights, and the contents of TA were determined in triplicates. To maximize recovery of genes involved in TA biosynthesis, the $5 \mathrm{~d}$-old hairy roots showing the highest increase and the 15d-old hairy roots achieving maximum alkaloid content were selected as transcriptome study materials based on the time course of alkaloid production. Total RNAs of the representative 5d-old and 15d-old hairy roots were extracted, and cDNA libraries were generated and sequenced on a Hiseq platform (Personalbio, Shanghai, China). De novo assemled transcriptomes of $A$. acutangulus hairy roots, $A$. belladonna hairy roots, and $D$. stramonium hairy roots were generated using Trinity (r20140717, K-mer $25 \mathrm{bp}$ ), and 229,401 unigenes, 163,301 unigenes, and 103,470 unigenes were obtained, respectively. Databases including NR, GO, KEGG, eggNOG, and SwissProt were used for unigene function annotation.

Gene cloning of plant type III PKSs. Total RNAs were extracted from hairy roots with Total RNA isolation kit (Promega), and quantified using NanoDrop 2000C (Thermo Scientific). In all, $1 \mu \mathrm{g}$ of total RNA was used to prepare cDNA using SMARTer RACE 5'/3' Kit (Clontech Laboratories, Inc.). Full-length AaPKSs, $A b P K S$ s, and DsPKSs were obtained using 5'-RACE and 3'-RACE PCR with primers listed in Supplementary Table 2.

Multiple sequence alignment and phylogenetic analysis. Sequences of $A a \mathrm{PKS}$, $A b$ PKSs, DsPKSs, and representative plant and bacterial type III PKSs were aligned by MUSCLE implemented in MEGA version 7.0.14 ${ }^{41}$, and visualized by GeneDoc version 2.7. The phylogenetic tree was generated with MEGA version 7.0.14 using the Maximum Likelihood method, a bootstrap test of 2000 replicates, and the Jones-Taylor-Thornton model using default parameters.

Protein expression and purification. The full-length sequences of $A a P Y K S$, $A b P Y K S, A b P K S 2, D s P Y K S$ were amplified from hairy root cDNA respectively using the primers listed in Supplementary Table 2. The PCR products were confirmed by agarose gel electrophoresis, purified by gel extraction kit (omega, D2500-02), digested by EcoRI/Sal I (AaPYKS) or BamHI/SalI (AbPYKS, AbPKS2, and DsPYKS), ligated to $\mathrm{pET} 28 \mathrm{a}$ vector digested by the corresponding restriction enzymes using T4 ligase, and transformed into chemically competent $E$. coli cells DH5a. Recombinant colonies were selected on LB agar plates supplemented with kanamycin $\left(50 \mu \mathrm{g} \mathrm{mL}^{-1}\right)$. Positive clones were identified by colony PCR and the corresponding plasmids were isolated and confirmed by sequencing and restriction enzyme digestion. Site mutated pET28a-AaPYKSs were obtained by fusion PCR using wild pET28a-AbPYKS as template and the primers are listed in Supplementary Table 2

The E. coli Rosetta (DE3) cells containing pET28a-AaPYKS, -AbPYKS, -AbPKS2, -DsPYKS or site mutated AaPYKS were cultured in LB liquid medium supplemented with kanamycin $\left(50 \mu \mathrm{g} \mathrm{mL}^{-1}\right)$ and chloramphenicol $\left(25 \mu \mathrm{g} \mathrm{mL}^{-1}\right)$ at $37^{\circ} \mathrm{C}$ in a shaker at $200 \mathrm{rpm}$. The protein expression was induced with IPTG ( $0.1 \mathrm{~mm}$ for $A b \mathrm{PYKS}, A b \mathrm{PKS} 2$, and $D s \mathrm{PYKS} ; 0.5 \mathrm{~mm}$ for wild $A a \mathrm{PYKS}$ and site mutated $A a$ PYKS) for $18-20 \mathrm{~h}$ at $16^{\circ} \mathrm{C}$ when $\mathrm{OD}_{600}$ reached 0.6.

Cell pellets were collected at $4^{\circ} \mathrm{C}$ by centrifugation and re-suspended in $50 \mathrm{~mL}$ ice-cold Buffer A (15 mm imidazole, $50 \mathrm{~mm}$ Tris, $300 \mathrm{~mm} \mathrm{NaCl}, 10 \%$ glycerol, 
$\mathrm{pH} 8.0$ ) and lysed by sonication for 4 min on ice. The supernatant was collected by centrifugation at $24,000 \mathrm{rpm}$ for $30-60 \mathrm{~min}$, filtered through $0.22 \mu \mathrm{m}$ filter, and loaded onto a HisTrap FF $5 \mathrm{~mL}$ column. The samples were eluted by a linear imidazole gradient of buffer A and buffer B (500 mm imidazole, $50 \mathrm{~mm}$ Tris, $300 \mathrm{~mm} \mathrm{NaCl}, 10 \%$ glycerol, pH 8.0). Fractions containing PKSs were concentrated to $10 \mathrm{mg} \mathrm{mL}^{-1}$ in storage buffer $\left(100 \mathrm{~mm} \mathrm{NaH} \mathrm{PO}_{4}, 10 \%\right.$ glycerol, $\left.\mathrm{pH} 7.0\right)$ with Amicon Ultra-4 centrifugal filters (Ultracel, $10,000 \mathrm{NMWL}$ ) and stored at $-80^{\circ} \mathrm{C}$.

Synthesis of chemical compound 1. 4-Aminobutyraldehydediethylacetal s-1 $(1.61 \mathrm{~g}, 10.0 \mathrm{mmol})$ was dissolved in THF $(50 \mathrm{~mL})$, then $\mathrm{NEt}_{3}(2.78 \mathrm{~mL}$, $20.0 \mathrm{mmol})$, di-tert-butyldicarbonate $(4.36 \mathrm{~g}, 20.0 \mathrm{mmol})$ and DMAP $(37 \mathrm{mg}$, $0.3 \mathrm{mmol}$ ) were added. The mixture was stirred at room temperature for $18 \mathrm{~h}$, and then all volatiles were removed in vacuo. The pure product was obtained by column chromatography on silica gel eluting with petroleum ether/EtOAc (5:1) to afford the compound $\mathbf{s}-2$ as a colorless oil $(2.51 \mathrm{~g}, 96 \%)^{42}$.

Sodium hydride ( $60 \%$ dispersion in oil, $183 \mathrm{mg}, 4.58 \mathrm{mmol}$ ) was added to a solution of s-2 $(1.00 \mathrm{~g}, 3.82 \mathrm{mmol})$ in DMF $(5 \mathrm{~mL})$. After $1 \mathrm{~h}$, iodomethane $(0.36 \mathrm{~mL}, 5.73 \mathrm{mmol})$ was added and the resulting mixture stirred at $\mathrm{rt}$ for $18 \mathrm{~h}$. It was poured into water $(100 \mathrm{~mL})$ and extracted with EtOAc $(3 \times 50 \mathrm{~mL})$. The organic portion was washed with brine $(5 \times 60 \mathrm{~mL})$, dried with $\mathrm{Na}_{2} \mathrm{SO}_{4}$, filtered and evaporated in vacuo. The pure product was obtained by column chromatography on silica gel eluting with petroleum ether/EtOAc (5:1) to afford the compound s-3 $(0.84 \mathrm{~g}, 80 \%) .{ }^{1} \mathrm{H}$ NMR $\left(400 \mathrm{MHz}, \mathrm{CDCl}_{3}\right): \delta 4.45(\mathrm{~s}, 1 \mathrm{H}), 3.65-3.54(\mathrm{~m}, 2 \mathrm{H})$, 3.49-3.37 (m, $2 \mathrm{H}), 3.17$ (s, $2 \mathrm{H}), 2.19(\mathrm{~s}, 3 \mathrm{H}), 1.62-1.56(\mathrm{~m}, 4 \mathrm{H}), 1.41(\mathrm{~s}, 9 \mathrm{H})$ $1.19-1.12(\mathrm{~m}, 6 \mathrm{H}) ;{ }^{13} \mathrm{C}$ NMR $\left(100 \mathrm{MHz}, \mathrm{CDCl}_{3}\right): \delta 155.7,102.5,79.0,61.04,60.97$, $33.9,30.7,28.3,15.2$ (One carbon signal for $\mathrm{CH}_{2}$ overlapped) ${ }^{43}$.

A solution of compound s-3 $(275 \mathrm{mg}, 1.0 \mathrm{mmol})$ in $\mathrm{MeOH}(1.6 \mathrm{~mL})$ was cooled in an ice bath for $10 \mathrm{~min}$. A solution of $\mathrm{HCl}(4 \mathrm{M}, 1.6 \mathrm{~mL})$ was added dropwise. Then the mixture was stirred at $0{ }^{\circ} \mathrm{C}$ for $20 \mathrm{~min}$ and then at $\mathrm{rt}$ for $16 \mathrm{~h}$, which was used for enzymatic reaction directly. Compound s-4: HRESIMS $(m / z):[\mathrm{M}+\mathrm{H}]^{+}$ calcd. for $\mathrm{C}_{5} \mathrm{H}_{12} \mathrm{NO}, 102.0913$; found, 102.0915. Compound 1: HREIMS $(\mathrm{m} / \mathrm{z})$ : $[\mathrm{M}]^{+}$calcd. for $\mathrm{C}_{5} \mathrm{H}_{10} \mathrm{~N}^{+}$, 84.0808; found, 84.0809.

$\mathrm{MeOH}$ was removed in vacuo, and the aqueous layer was washed with ether to remove organic impurities. Water was evaporated under vacuum using a rotary evaporator, leaving the final compound in an oil state. ${ }^{1} \mathrm{H},{ }^{13} \mathrm{C}$ NMR (Supplementary Fig. 17 and 18) and high-resolution mass spectra of compound 1 were collected to confirm product identity. ${ }^{1} \mathrm{H}$ NMR $\left(400 \mathrm{MHz}, \mathrm{D}_{2} \mathrm{O}\right): \delta 4.27-4.13$ (m, $2 \mathrm{H}), 3.63$ (s, $3 \mathrm{H}), 3.19$ (brs, $2 \mathrm{H}), 3.11-2.97(\mathrm{~m}, 1 \mathrm{H}), 2.39-2.29(\mathrm{~m}, 2 \mathrm{H}) ;{ }^{13} \mathrm{C}$ NMR $\left(100 \mathrm{MHz}, \mathrm{D}_{2} \mathrm{O}\right): \delta 181.6,60.6,40.4,35.7,19.5$.

Synthesis of chemical compound (S) $-\mathbf{3}$. Thionyl chloride $(2.61 \mathrm{~mL}, 36.0 \mathrm{mmol})$ dissolved in $\mathrm{CHCl}_{3}(15 \mathrm{~mL})$ was added slowly to an ice-cold solution of $(S)-\mathrm{N}$ methyl-2-(hydroxymethyl)pyrrolidine s-5 $(3.46 \mathrm{~g}, 30 \mathrm{mmol})$ in $\mathrm{CHCl}_{3}(30 \mathrm{~mL})$ stirred in a $\mathrm{N}_{2}$ atmosphere. After the addition, the reaction mixture was stirred at $\mathrm{rt}$ for $2 \mathrm{~h}$ and then refluxed for $30 \mathrm{~min}$. The solvent was then removed in vacuo and the residue dissolved in a small amount of absolute $\mathrm{EtOH}$. $\mathrm{Et}_{2} \mathrm{O}$ was added and $(S)$ $\mathrm{N}$-methyl-2-(chloromethyl)pyrrolidine hydrochloride s-6 was separated $(4.75 \mathrm{~g}$, 93\% $)^{9}$

(S)-N-Methyl-2-(chloromethyl)pyrrolidine hydrochloride s-6 (4.75 g, 27.9 $\mathrm{mmol}$ ) was dissolved in $80 \%$ aqueous $\mathrm{EtOH}(75 \mathrm{~mL})$ and cooled in an ice bath $\mathrm{NaHCO}_{3}(2.62 \mathrm{~g}, 31.2 \mathrm{mmol})$ dissolved in water $(35 \mathrm{~mL})$ was slowly added and the mixture stirred for $15 \mathrm{~min}$. Sodium cyanide $(2.05 \mathrm{~g}, 41.8 \mathrm{mmol})$ was added and the mixture refluxed for $30 \mathrm{~min}$. The $\mathrm{EtOH}$ was then removed in vacuo and the residue extracted with EtOAc $(3 \times 50 \mathrm{~mL})$. The dried extract $\left(\mathrm{Na}_{2} \mathrm{SO}_{4}\right)$ was evaporated and the residual oil was chromatographed on silica gel eluting with petroleum ether/ EtOAc (1:1) to afford (S)- $N$-methyl-2-(cyanomethyl)pyrrolidine s-7 (2.60 g, 75\% yield $)^{9}$.

(S)-N-Methyl-2-(cyanomethyl)pyrrolidine s-7 $(620 \mathrm{mg}, 0.50 \mathrm{mmol})$ was added to concentrated $\mathrm{HCl}(2 \mathrm{~mL})$ and the mixture refluxed for $2 \mathrm{~h}$. The solution was evaporated to dryness and the residue dissolved in water $(1 \mathrm{~mL})$. The aqueous solution was adjusted to $\mathrm{pH} 8-9$ with $2 \mathrm{M} \mathrm{NaOH}$ aqueous solution and then evaporated to dryness. The residue was washed with $\mathrm{CH}_{2} \mathrm{Cl}_{2}(10 \times 3 \mathrm{~mL})$, the combined $\mathrm{CH}_{2} \mathrm{Cl}_{2}$ was dried with $\mathrm{Na}_{2} \mathrm{SO}_{4}$, filtered and evaporated in vacuo to give (S)-N-Methylpyrrolidine-2-acetic acid s-8 (198 mg, 27.6\%). ${ }^{1} \mathrm{H}$ NMR $(400 \mathrm{MHz}$, $\mathrm{CDCl}_{3}$, Supplementary Fig. 19): $\delta 9.90$ (brs, $\left.1 \mathrm{H}\right), 3.58$ (brs, $1 \mathrm{H}$ ), 3.21 (brs, $1 \mathrm{H}$ ), $2.73(\mathrm{~s}, 3 \mathrm{H}), 2.80-2.53(\mathrm{~m}, 3 \mathrm{H}), 2.28-2.17(\mathrm{~m}, 1 \mathrm{H}), 2.10-1.49(\mathrm{~m}, 3 \mathrm{H}) ;{ }^{13} \mathrm{C} \mathrm{NMR}$ (100 MHz, $\mathrm{CDCl}_{3}$, Supplementary Fig. 20): $\delta 173.9,64.4,55.6,39.4,35.1,30.0,22.2$.

$1,1^{\prime}$-Carbonyldiimidazole $(62.2 \mathrm{mg}, 0.38 \mathrm{mmol})$ was taken in a $25 \mathrm{~mL}$ flamedried Schlenk flask, which was under nitrogen atmosphere. The shlenk was charged with (S)-N-Methylpyrrolidine-2-acetic acid s-8 $(50.0 \mathrm{mg}, 0.35 \mathrm{mmol})$ in THF (1 $\mathrm{mL}$ ) and the reaction was stirred for $3 \mathrm{~h}$ at room temperature. Then methyl potassium malonate $(81.8 \mathrm{mg}, 0.52 \mathrm{mmol})$ and $\mathrm{MgCl}_{2}(39.8 \mathrm{mg}, 0.42 \mathrm{mmol})$ were added to the above solution and the reaction mixture was stirred for $16 \mathrm{~h}$. Water was added to the reaction mixture and extracted with EtOAc $(15 \mathrm{~mL} \times 3)$. The organic portion was dried with $\mathrm{Na}_{2} \mathrm{SO}_{4}$, filtered and evaporated in vacuo, and the residual oil was chromatographed on silica gel eluting with $\mathrm{CH}_{2} \mathrm{Cl}_{2} / \mathrm{MeOH}(40: 1)$ to afford compound $(S)-\mathbf{3}$ as a yellow oil $(24.9 \mathrm{mg}, 35.7 \%)$. ${ }^{1} \mathrm{H}$ NMR $(400 \mathrm{MHz}$, acetone- $d_{6}$, Supplementary Fig. 21): $\delta 3.54(\mathrm{~s}, 3 \mathrm{H}), 3.44(\mathrm{~s}, 2 \mathrm{H}), 2.86-2.74$ (m, $2 \mathrm{H}), 2.46-2.36(\mathrm{~m}, 2 \mathrm{H}), 2.12(\mathrm{~s}, 3 \mathrm{H}), 2 . .00(\mathrm{q}, J=8.0 \mathrm{~Hz}, 1 \mathrm{H}), 1.93-1.85$ (m, $1 \mathrm{H}), 1.47-1.49(\mathrm{~m}, 2 \mathrm{H}), 1.32-1.23(\mathrm{~m}, 1 \mathrm{H}) ;{ }^{13} \mathrm{C}$ NMR (100 MHz, acetone- $d_{6}$, Supplementary Fig. 22): $\delta 202.8,168.4,62.3,57.3,52.2,50.2,47.9,40.6,31.7,22.8$.

Synthesis of chemical compounds (S)-4 and (S)-2. A solution of $\mathrm{KOH}(0.98 \mathrm{~g}$, $17.6 \mathrm{~mol}$ ) in benzyl alcohol (17.6 mL) was added gradually to a solution of dibenzyl malonate $(5.00 \mathrm{~g}, 17.6 \mathrm{mmol})$ in benzyl alcohol $(44 \mathrm{~mL})$. The reaction mixture was stirred for $4 \mathrm{~h}$ at ambient temperature, and diluted with diethyl ether $(250 \mathrm{~mL})$, resulting in a white precipitate. The mixture was stirred for $30 \mathrm{~min}$ and the product was removed by filtration, washed with diethyl ether $(3 \times 20 \mathrm{~mL})$, and air-dried to give benzyl potassium malonate as a white solid $(3.34 \mathrm{~g}, 82 \%)^{44}$.

$1,1^{\prime}$-Carbonyldiimidazole $(62.2 \mathrm{mg}, 0.38 \mathrm{mmol})$ was taken in a $25 \mathrm{~mL}$ flamedried Schlenk flask, which was under nitrogen atmosphere. The shlenk was charged with (S)-N-Methylpyrrolidine-2-acetic acid s-8 $(50.0 \mathrm{mg}, 0.35 \mathrm{mmol})$ in THF $(1 \mathrm{~mL})$ and the reaction was stirred for $3 \mathrm{~h}$ at room temperature. Then benzyl potassium malonate $(121 \mathrm{mg}, 0.52 \mathrm{mmol})$ and $\mathrm{MgCl}_{2}(39.8 \mathrm{mg}, 0.42 \mathrm{mmol})$ were added to the above solution and the reaction mixture was stirred for $16 \mathrm{~h}$. Water is added to the reaction mixture and extracted with EtOAc $(15 \mathrm{~mL} \times 3)$. The organic portion was dried with $\mathrm{Na}_{2} \mathrm{SO}_{4}$, filtered and evaporated in vacuo, and the residual oil was chromatographed on silica gel eluting with a mixture of $\mathrm{CH}_{2} \mathrm{Cl}_{2}$ and $\mathrm{MeOH}$ $(40: 1)$ to afford compound $(S)-4$ as a yellow oil $(32.7 \mathrm{mg}, 34.0 \%)$. $[\alpha]_{\mathrm{D}}{ }^{37}=-31.2$ $\left(c 0.1, \mathrm{H}_{2} \mathrm{O}\right) .{ }^{1} \mathrm{H}$ NMR $\left(400 \mathrm{MHz}\right.$, acetone- $d_{6}$, Supplementary Fig. 23$): \delta 7.35-7.12$ $(\mathrm{m}, 5 \mathrm{H}), 5.03(\mathrm{~s}, 2 \mathrm{H}), 3.49(\mathrm{~s}, 2 \mathrm{H}), 2.84-2.73(\mathrm{~m}, 2 \mathrm{H}), 2.46-2.36(\mathrm{~m}, 2 \mathrm{H}), 2.10(\mathrm{~s}$, $3 \mathrm{H}), 2.03-1.95(\mathrm{~m}, 1 \mathrm{H}), 1.92-1.81(\mathrm{~m}, 1 \mathrm{H}), 1.55-1.47(\mathrm{~m}, 2 \mathrm{H}), 1.30-1.20(\mathrm{~m}$, $1 \mathrm{H}) .{ }^{13} \mathrm{C}$ NMR (acetone- $d_{6}$, Supplementary Fig. 24 ): $\delta 202.9,168.0,137.2,129.4$, $129.2,129.1,67.2,62.5,57.4,50.5,48.1,40.8,31.8,23.0$. HRESIMS $(m / z):[\mathrm{M}+\mathrm{H}]^{+}$ calcd. for $\mathrm{C}_{16} \mathrm{H}_{22} \mathrm{NO}_{3}, 276.1594$; found, 276.1599 .

A solution of the benzyl ester $(S)-4(20 \mathrm{mg}, 0.073 \mathrm{mmol})$ in methanol $(2 \mathrm{~mL})$ was stirred with $10 \% \mathrm{Pd} / \mathrm{C}(2 \mathrm{mg})$ under hydrogen $(1 \mathrm{~atm})$ at room temperature for $16 \mathrm{~h}$. The mixture was then filtered through Celite and the solvent was evaporated in vacuo to give compound $(S)-2$, which is unstable. HRESIMS $(m / z):[\mathrm{M}+\mathrm{H}]^{+}$ calcd. for $\mathrm{C}_{9} \mathrm{H}_{16} \mathrm{NO}_{3}, 186.1125$; found, 186.1124 .

Synthesis of chemical compounds $\mathbf{4}$ and $2.1 \mathrm{~mL}$ of $\mathbf{1}$ (in $\mathrm{MeOH} / \mathrm{H}_{2} \mathrm{O}=1: 1$ ) and $200 \mathrm{mg}$ of 5 were added to $19 \mathrm{~mL}$ of potassium phosphate buffer $\left(50 \mathrm{~mm} \mathrm{~K} \mathrm{HPO}_{4} /\right.$ $\mathrm{KH}_{2} \mathrm{PO}_{4}, \mathrm{pH} 8.0$ ). The mix was stirred at $30^{\circ} \mathrm{C}$ for $3 \mathrm{~h}$ and quenched with $20 \mathrm{~mL}$ of $200 \mathrm{~mm}$ ammonium acetate solution and $0.94 \mathrm{~mL}$ of formic acid (88\% stock solution). Compound 2: MS $(m / z):[M+H]^{+}$; calcd. for $\mathrm{C}_{9} \mathrm{H}_{16} \mathrm{NO}_{3}, 186$; found, 186 .

The mixture containing compound $\mathbf{2}$ was then dried by freeze dryer, and the product was further dissolved in $1 \mathrm{~mL}$ of benzyl alcohol. $0.1 \mathrm{~mL}$ of thionyl chloride was added dropwise to this solution. The resulting solution was heated at $65^{\circ} \mathrm{C}$ for $\sim 6 \mathrm{~h}$ and the crude product was the benzyl product of 2 , compound $4 .[\alpha]_{\mathrm{D}}{ }^{37}=$ $-6.5\left(c 0.4, \mathrm{H}_{2} \mathrm{O}\right)$. Compound 4: MS $(\mathrm{m} / z)$ : $[\mathrm{M}+\mathrm{H}]^{+}$; calcd. for $\mathrm{C}_{16} \mathrm{H}_{22} \mathrm{NO}_{3}, 276$ found, 276 .

Enzymatic assays and LC-MS analysis. All reactions were performed in potassium phosphate buffer $\left(50 \mathrm{~mm} \mathrm{~K} \mathrm{~K}_{2} \mathrm{HO}_{4} / \mathrm{KH}_{2} \mathrm{PO}_{4}, \mathrm{pH}\right.$ 8.0). For detection of formation of compound 2 , a reaction mixture $(100 \mu \mathrm{L}$ ) containing $5 \mu \mathrm{L} \mathbf{1}$ (in $\mathrm{MeOH} /$ $\mathrm{H}_{2} \mathrm{O}=1: 1$ ), $0.5 \mathrm{~mm}$ malonyl-CoA (Sigma-Aldrich, M4263), and $7 \mu \mathrm{m}$ protein (AaPYKS, $A b$ PYKS, $A b$ PKS2, or DsPYKS) was incubated at $30^{\circ} \mathrm{C}$ for $2 \mathrm{~h}$. For detection of formation of compound $\mathbf{5}$, a reaction mixture $(100 \mu \mathrm{L})$ containing 0.5 mm malonyl-CoA and $15 \mu \mathrm{m} A a$ PYKS was incubated at $30^{\circ} \mathrm{C}$ for $2 \mathrm{~h}$. The reactions were stopped by addition of $100 \mu \mathrm{L}$ ammonium acetate solution $(200 \mathrm{~mm}$ stock solution), $4 \mu \mathrm{L}$ formic acid (88\% stock solution) and $6 \mu \mathrm{L}$ methanol. A $10 \mu \mathrm{L}$ aliquot of the reaction mixture was subject to LC-MS analysis eluted with a flow rate of $1 \mathrm{~mL} \mathrm{~min}-1$ over a $25 \mathrm{~min}$ gradient with water and acetonitrile $(t=0 \mathrm{~min}, 5 \%$ acetonitrile; $t=10 \mathrm{~min}, 5 \%$ acetonitrile; $t=10.1 \mathrm{~min}, 50 \%$ acetonitrile; $t=20 \mathrm{~min}$, $50 \%$ acetonitrile; $t=20.1 \mathrm{~min}, 100 \%$ acetonitrile) on a HITACHI LaChrom C8 column $(4.6 \mathrm{~mm} \times 250 \mathrm{~mm}$, i.d., $5 \mu \mathrm{m})$ at $25^{\circ} \mathrm{C}$. Formic acid (final concentration, $0.1 \%$ ) was added to the mobile phases for analyzing compound 5 .

Thionyl chloride $(0.069 \mathrm{mmol}, 5 \mu \mathrm{L})$ was added dropwise to a solution of enzymatic product 2 (estimated at $0.005 \mathrm{mmol}, 1.0 \mathrm{mg}$ ) in methanol/benzyl alcohol $(1 \mathrm{~mL})$. The resulting solution was heated at $65^{\circ} \mathrm{C}$ for $\sim 6 \mathrm{~h}$ and the crude product was the methyl and the benzyl product of 2 , respectively.

For synthesized methyl 4-(1-methylpyrrolidinyl)-3-oxobutanoate (3), benzyl 4(1-methylpyrrolidinyl)-3-oxobutanoate (4), and the methyl or the benzyl product of 2, LC-MS analysis was performed on a YMC-Triant C18 column (4.6 mm I.D. $\times$ $250 \mathrm{mmL}$ ) at a flow rate of $1 \mathrm{~mL} \mathrm{~min}^{-1}$ over a $28 \mathrm{~min}$ gradient with water and methanol ( $t=0 \mathrm{~min}, 10 \%$ methanol; $t=20 \mathrm{~min}, 100 \%$ methanol; $t=24 \mathrm{~min}, 100 \%$ methanol; $t=24.1 \mathrm{~min}, 10 \%$ methanol; $t=28 \mathrm{~min}, 10 \%$ methanol). The column temperature was $25^{\circ} \mathrm{C}$, and formic acid (final concentration, $0.1 \%$ ) was added to the mobile phases.

For kinetic assays, potassium phosphate buffer $\left(50 \mathrm{~mm} \mathrm{~K} \mathrm{HPO}_{4} / \mathrm{KH}_{2} \mathrm{PO}_{4}, \mathrm{pH}\right.$ 8.0) containing $1 \mathrm{~mm}$ of compound 5 (Sigma-Aldrich, $165115-25 \mathrm{G}$ ) at $30^{\circ} \mathrm{C}$ was added $A a$ PYKS or boiled AaPYKS to $5.6 \mu \mathrm{M}$ and the indicated amount of compound 1 to initiate the reaction (total volume was $50 \mu \mathrm{L}$ ). After 5 min incubation, the reactions were stopped and measured as described. Quantification was performed based on standard curves for synthesized methyl compound $\mathbf{3}$ and its degradation products, hygrine, and compound $2^{17}$. 
The large-scale enzyme reaction was performed as described in the Synthesis of chemical compounds $\mathbf{4}$ and $\mathbf{2}$ part in the present of $6 \mu \mathrm{M} A a \mathrm{PYKS}$. The benzyl modification product of $\mathbf{2}$ was purified by HPLC using the same gradient elution program as that for the LC-MS analysis, and its stereochemistry was studied. $[\alpha]_{\mathrm{D}}^{37}=-4.5\left(c 0.40, \mathrm{H}_{2} \mathrm{O}\right)$.

Crystallization and structure determination of AaPYKS. For preparation of AaPYKS, E. coli Rosetta (DE3) cells carrying pET28a-AaPYKS were cultured in LB at $37^{\circ} \mathrm{C}$, and the expression of $N$-terminal 6 xHis-tagged $A a \mathrm{PYKS}$ was induced at $18^{\circ} \mathrm{C}$ for $16 \mathrm{~h}$ with $0.5 \mathrm{~mm}$ IPTG at $\mathrm{OD}_{600}$ of 0.8 . Cells were harvested by centrifugation $\left(8000 \mathrm{~g}, 4^{\circ} \mathrm{C}\right)$, re-suspended in lysis buffer $(50 \mathrm{~mm}$ Tris- $\mathrm{HCl} \mathrm{pH} \mathrm{8.0,}$ $0.3 \mathrm{M} \mathrm{NaCl}$, $5 \%$ (v/v) glycerol, $5 \mathrm{~mm} \beta$-mercaptoethanol, protease inhibitor cocktail (bimake.cn)) and lysed using an Avestin EmulsiFlex-C3 cell disrupter (Avestin, Inc.). The lysate was centrifuged $\left(16,000 \mathrm{~g} ; 45 \mathrm{~min} ; 4^{\circ} \mathrm{C}\right.$ ) and the supernatant was loaded on to a $2 \mathrm{~mL}$ column packed with Ni-NTA agarose (SMART, Inc.). The protein was washed by lysis buffer containing 20, $40 \mathrm{~mm}$ imidazole and eluted with lysis buffer containing $500 \mathrm{~mm}$ imidazole. The eluted fractions were loaded on a HiLoad 16/60 Superdex S200 column (GE Healthcare, Inc.) equilibrated in $10 \mathrm{~mm}$ Tris-HCl pH 8.0, $0.1 \mathrm{~m} \mathrm{NaCl}, 1 \%(\mathrm{v} / \mathrm{v})$ glycerol, 1 mм DTT. Fractions containing AaPYKS were collected, concentrated to $15 \mathrm{mg} \mathrm{mL}^{-1}$, and stored at $-80^{\circ} \mathrm{C}$.

Crystals of $A a$ PYKS-COB were grown by vapor diffusion at $4{ }^{\circ} \mathrm{C}$ in $2 \mu \mathrm{L}$ drops containing a $1: 1$ mixture of $15 \mathrm{mg} \mathrm{mL}^{-1}$ protein and crystallization buffer $(1 \% \mathrm{w} / \mathrm{v}$ Tryptone, 0.05 м HEPES sodium 7.0, 12\% PEG3,350 (w/v), 1 mM Sodium azide). AaPYKS-COB crystals grown 7 days were harvested for X-ray diffraction data collection. AaPYKS- 6 crystals were obtained by soaking the AaPYKS-COB crystals in crystallization buffer containing $10 \mathrm{~mm}$ malonyl-CoA. Crystals were transferred and stabilized in crystallization buffer containing $21 \%$ ethylene glycol and cooled in liquid nitrogen.

Data were collected at Shanghai Synchrotron Radiation Facility beamlines $17 \mathrm{U}$ and 19U1, processed using HKL2000 ${ }^{45}$. The structure was solved by molecular replacement with Phaser $\mathrm{MR}^{46}$ using the structure of chalcone synthase (PDB: 1BI5) as the search model. Cycles of iterative model building and refinement were performed in $\operatorname{Coot}^{47}$ and Phenix ${ }^{48}$.

LC-MS/MS analysis of AaPYKS. AaPYKS protein $(50 \mu \mathrm{g})$ was loaded onto a PD Minitrap G-25 column (GE Healthcare, USA) equilibrated with water to remove salt contamination. The AaPYKS fractions were collected and digested with $1 \mu \mathrm{g}$ of trypsin (Promega) in $50 \mu \mathrm{L}$ of $50 \mathrm{~mm} \mathrm{NH}_{4} \mathrm{HCO}_{3}$ for $16 \mathrm{~h}$ at $37^{\circ} \mathrm{C}$. The samples were subsequently evaporated to dryness. Peptides were then analyzed in an Orbitrap Fusion Lumos Mass spectrometer (Thermo Scientific, USA). Peptide fragmentation was performed via higher-energy collision dissociation. Data processing was performed using Proteome Discoverer 2.1 software (Thermo Scientific, USA) and peptide sequences were determined by matching protein databases with the acquired fragmentation pattern by SEQUEST HT algorithm. The precursor mass tolerance was set to $10 \mathrm{ppm}$ and fragment ion mass tolerance to $0.05 \mathrm{Da}$.

Reporting summary. Further information on research design is available in the Nature Research Reporting Summary linked to this article.

\section{Data availability}

RNA-Seq data that support the findings of this study have been deposited in National Center for Biotechnology Information (NCBI) Sequence Read Archive (SRA) with accession numbers SRR9888534, SRR9888536, and SRR9888538. The GenBank accession numbers for AaPYKS, DsPYKS, and AbPKS2 are MN025472, MN025473, and MN025474, respectively. The PDB IDs for AaPYKS-COB and AaPYKS-6 are 6J1M and $6 \mathrm{~J} 1 \mathrm{~N}$, respectively. The authors declare that all other relevant data supporting the findings of this study are available within the article, its Supplementary Information, and Source Data files.

Received: 2 June 2019 Accepted: 14 August 2019

Published online: 06 September 2019

\section{References}

1. Griffin, W. J. \& Lin, G. D. Chemotaxonomy and geographical distribution of tropane alkaloids. Phytochemistry 53, 623-637 (2000).

2. Fodor, G. \& Dharanipragada, R. Tropane alkaloids. Nat. Prod. Rep. 7, 539-548 (1990).

3. Grynkiewicz, G. \& Gadzikowska, M. Tropane alkaloids as medicinally useful natural products and their synthetic derivatives as new drugs. Pharmacol. Rep. 60, 439-463 (2008)

4. Leete, E., Marion, L. \& Spenser, I. D. Biogenesis of hyoscyamine. Nature 174, 650-651 (1954).

5. Leete, E. The stereospecific incorporation of ornithine into the tropine moiety of hyoscyamine. J. Am. Chem. Soc. 84, 55-57 (1962).
6. Leete, E. Biosynthesis of the pyrrolidine rings of cocaine and cuscohygrine from $\left[5^{-14} \mathrm{C}\right]$-ornithine via a symmetrical intermediate. J. Am. Chem. Soc. 104, 1403-1408 (1982)

7. Hashimoto, T., Yamada, Y. \& Leete, E. Species-dependent biosynthesis of hyoscyamine. J. Am. Chem. Soc. 111, 1141-1142 (1989).

8. Leete, E. \& Kim, S. H. A revision of the generally accepted hypothesis for the biosynthesis of the tropane moiety of cocaine. J. Am. Chem. Soc. 110 2976-2978 (1988).

9. Leete, E., Bjorklund, J. A., Couladis, M. M. \& Kim, S. H. Late intermediates in the biosynthesis of cocaine: 4-(1-Methyl-2-pyrrolidinyl)-3-oxobutanoate and methyl ecgonine. J. Am. Chem. Soc. 113, 9286-9292 (1991).

10. Hemscheidt, T. \& Spenser, I. D. Biosynthesis of $6 \beta$-hydroxytropine in Datura stramonium: nonregiospecific incorporation of $\left[1,2-{ }^{13} \mathrm{C}_{2}\right]$ acetate. J. Am. Chem. Soc. 114, 5472-5473 (1992).

11. Docimo, T. et al. The first step in the biosynthesis of cocaine in Erythroxylum coca: The characterization of arginine and ornithine decarboxylases. Plant Mol. Biol. 78, 599-615 (2012).

12. Hashimoto, T., Yun, D. J. \& Yamada, Y. Putrescine and putrescine $N$ methyltransferase in the biosynthesis of tropane alkaloids in cultured roots of Hyoscyamus albus. Planta 178, 123-130 (1989).

13. Biastoff, S., Brandt, W., Dräger, B. \& Putrescine $N$-methyltransferase-the start for alkaloids. Phytochemistry 70, 1708-1718 (2009).

14. Heim, W. G. et al. Cloning and characterization of a Nicotiana tabacum methylputrescine oxidase transcript. Phytochemistry 68, 454-463 (2007).

15. Katoh, A., Shoji, T. \& Hashimoto, T. Molecular cloning of $N$-methylputrescine oxidase from tobacco. Plant Cell Physiol. 48, 550-554 (2007).

16. Friesen, J. B. \& Leete, E. Nicotine synthase - an enzyme from nicotiana species which catalyzes the formation of $(S)$-nicotine from nicotinic acid and 1methyl- $\delta$ pyrrolinium chloride. Tetrahedron Lett. 31, 6295-6298 (1990).

17. Bedewitz, M. A., Jones, A. D., D’Auria, J. C. \& Barry, C. S. Tropinone synthesis via an atypical polyketide synthase and P450-mediated cyclization. Nat. Commun. 9, 5281 (2018).

18. Humphrey, A. J. \& O'Hagan, D. Tropane alkaloid biosynthesis. A century old problem unresolved. Nat. Prod. Rep. 18, 494-502 (2001).

19. Zheng, G., He, J. \& Wang, S. The influence of callus differentiation of Anisodus acutangulus on the contents of hyoscyamine and scopolamine. Acta Phytophysiol. Sin. 6, 377-385 (1980).

20. Hashimoto, T. et al. Hyoscyamine $6 \beta$-hydroxylase, an enzyme involved in tropane alkaloid biosynthesis, is localized at the pericycle of the root. J. Biol. Chem. 266, 4648-4653 (1991)

21. Nakajima, K. \& Hashimoto, T. Two tropinone reductases, that catalyze opposite stereospecific reductions in tropane alkaloid biosynthesis, are localized in plant root with different cell-specific patterns. Plant Cell Physiol. 40, 1099-1107 (1999).

22. Georgiev, M. I., Pavlov, A. I. \& Bley, T. Hairy root type plant in vitro systems as sources of bioactive substances. Appl. Microbiol. Biotechnol. 74, 1175-1185 (2007).

23. Robins, R. J., Abraham, T. W., Parr, A. J., Eagles, J. \& Walton, N. J. The biosynthesis of tropane alkaloids in Datura stramonium: The identity of the intermediates between $\mathrm{N}$-methylpyrrolinium salt and tropinone. J. Am. Chem. Soc. 119, 10929-10934 (1997).

24. Abraham, T. W. \& Leete, E. New intermediate in the biosynthesis of the tropane alkaloids in Datura innoxia. J. Am. Chem. Soc. 117, 8100-8105 (1995).

25. Newquist, M. L., Abraham, T. W. \& Leete, E. Biosynthetic incorporation of ethyl $(R S)\left[2,3-{ }^{13} \mathrm{C}_{2}, 3-{ }^{14} \mathrm{C}\right]-4$-(1-methyl-2-pyrrolidinyl)-3-oxobutanoate into cuscohygrine in Erythroxylum coca. Phytochemistry 33, 1437-1440 (1993).

26. Austin, M. B. \& Noel, J. P. The chalcone synthase superfamily of type III polyketide synthases. Nat. Prod. Rep. 20, 79-110 (2003).

27. Abe, I. \& Morita, H. Structure and function of the chalcone synthase superfamily of plant type III polyketide synthases. Nat. Prod. Rep. 27, 809-838 (2010).

28. Morita, H. et al. Structural insight into chain-length control and product specificity of pentaketide chromone synthase from Aloe arborescens. Chem. Biol. 14, 359-369 (2007).

29. Shimizu, Y., Ogata, H. \& Goto, S. Type III polyketide synthases: functional classification and phylogenomics. ChemBioChem 18, 50-65 (2017).

30. Abe, I. et al. A plant type III polyketide synthase that produces pentaketide chromone. J. Am. Chem. Soc. 127, 1362-1363 (2005).

31. Abe, I., Oguro, S., Utsumi, Y., Sano, Y. \& Noguchi, H. Engineered biosynthesis of plant polyketides: chain length control in an octaketide-producing plant type III polyketide synthase. J. Am. Chem. Soc. 127, 12709-12716 (2005).

32. Abe, I., Watanabe, T., Morita, H., Kohno, T. \& Noguchi, H. Engineered biosynthesis of plant polyketides: manipulation of chalcone synthase. Org. Lett. 8, 499-502 (2006).

33. McGaw, B. A. \& Woolley, J. G. Stereochemistry of tropane alkaloid formation in Datura. Phytochemistry 17, 257-259 (1978). 
34. Morita, H. et al. A structure-based mechanism for benzalacetone synthase from Rheum palmatum. Proc. Natl. Acad. Sci. USA 107, 669-673 (2010).

35. Robinson, R. A synthesis of tropinone. J. Chem. Soc. Trans. 111, 762-768 (1917).

36. Kim, N., Estrada, O., Chavez, B., Stewart, C. Jr \& D’Auria, J. C. Tropane and granatane alkaloid biosynthesis: a systematic analysis. Molecules 21, 1510 (2016).

37. Hemscheidt, T. \& Spenser, I. D. Biosynthesis of lycopodine: incorporation of acetate via an intermediate with $C_{2 \mathrm{v}}$ symmetry. J. Am. Chem. Soc. 115 , 3020-3021 (1993).

38. Hemscheidt, T. \& Spenser, I. D. A classical paradigm of alkaloid biogenesis revisited: acetonedicarboxylic acid as a biosynthetic precursor of lycopodine. $J$. Am. Chem. Soc. 118, 1799-1800 (1996).

39. Qin, B. et al. Effects of acetylsalicylic acid and UV-B on gene expression and tropane alkaloid biosynthesis in hairy root cultures of Anisodus luridus. Plant Cell Tiss. Org. Cult. 117, 483-490 (2014).

40. Kamada, H., Okamura, N., Satake, M., Harada, H. \& Shimomura, K. Alkaloid production by hairy root cultures in Atropa belladonna. Plant Cell Rep. $\mathbf{5}$, 239-242 (1986).

41. Edgar, R. C. MUSCLE: multiple sequence alignment with high accuracy and high throughput. Nucleic Acids Res. 32, 1792-1797 (2004).

42. Nielsen, L., Lindsay, K. B., Faber, J., Nielsen, N. C. \& Skrydstrup, T. Stereocontrolled synthesis of methyl silanediol peptide mimics. J. Org. Chem. 72, 10035-10044 (2007).

43. Hillgren, J. M., Oberg, C. T. \& Elofsson, M. Syntheses of pseudoceramines A$\mathrm{D}$ and a new synthesis of spermatinamine, bromotyrosine natural products from marine sponges. Org. Biomol. Chem. 10, 1246-1254 (2012).

44. Bulman Page, P. C. et al. A. Short and versatile route to a key intermediate for lactacystin synthesis. Org. Lett. 5, 353-355 (2003).

45. Otwinowski, Z. \& Minor, W. Processing of X-ray diffraction data collected in oscillation mode. Methods Enzymol. 276, 307-326 (1997).

46. McCoy, A. J. et al. Phaser crystallographic software. J. Appl. Crystallogr. 40 658-674 (2007).

47. Emsley, P. \& Cowtan, K. Coot: model-building tools for molecular graphics. Acta Crystallogr. D Biol. Crystallogr. 60, 2126-2132 (2004).

48. Adams, P. D. et al. PHENIX: a comprehensive Python-based system for macromolecular structure solution. Acta Crystallogr. D Biol. Crystallogr. 66 , 213-221 (2010).

\section{Acknowledgements}

This research was supported by the National Key R\&D Program of China (2018YFA0900600), the Strategic Priority Research Program of the CAS (No.

XDB27020205), the National Natural Science Foundation of China (Nos. 81522044,

31822001 and U1702285), the Key Research Program of Frontier Sciences of the CAS
(No. QYZDB-SSW-SMC051), and the Research Foundations of Yunnan Province (Nos. 2019ZF011-2, 2013HA022, and 2018HC012).

\section{Author contributions}

S.-X.H. designed the research, and J.-P.H., C.F., Y.Z., and S.-X.H. wrote the paper. J.-P.H cloned all the genes and mutants, and carried out the in vitro chemical reactions and as well as HPLC analysis. C.F. and Y.Z. performed the protein crystallization and structure analysis. X.M. synthesized enzymatic reaction substrates and standards. X.M., L.W., J.Y., J.L., and Y.Y. analyzed the NMR data and performed the structures determination of synthesized compounds.

\section{Additional information}

Supplementary Information accompanies this paper at https://doi.org/10.1038/s41467019-11987-z.

Competing interests: The authors declare no competing interests.

Reprints and permission information is available online at http://npg.nature.com/ reprintsandpermissions/

Peer review information: Nature Communications thanks Peter Facchini, Rajan Sankaranarayanan and other anonymous reviewer(s) for their contribution to the peer review of this work.

Publisher's note: Springer Nature remains neutral with regard to jurisdictional claims in published maps and institutional affiliations.

(c) (i) Open Access This article is licensed under a Creative Commons Attribution 4.0 International License, which permits use, sharing, adaptation, distribution and reproduction in any medium or format, as long as you give appropriate credit to the original author(s) and the source, provide a link to the Creative Commons license, and indicate if changes were made. The images or other third party material in this article are included in the article's Creative Commons license, unless indicated otherwise in a credit line to the material. If material is not included in the article's Creative Commons license and your intended use is not permitted by statutory regulation or exceeds the permitted use, you will need to obtain permission directly from the copyright holder. To view a copy of this license, visit http://creativecommons.org/ licenses/by/4.0/.

(C) The Author(s) 2019 